\title{
The Influence of Group Big-Five Personality Composition on Student Engagement in Online Discussion
}

\author{
Xiaojie Zhang, Guang Chen, and Bing Xu
}

\begin{abstract}
To explore the influence of the group personality composition on students' engagement in the online discussion, correlation analysis was conducted among the Big-5 personality of group members and student engagement in the group. This study comprehensively used four measurement indicators of the Big-Five personality of group members as group composition: average, variance, maximum, and minimum. In this study, student engagement was divided into behavioral engagement, affective engagement, and cognitive engagement. The study found that the combination of the Big-Five personalities in the group could have an impact on student engagement, especially affective engagement. When organizing students' online discussion, the instructors need to consider the personality characteristics of the group members carefully.
\end{abstract}

Index Terms-Five-factor personality, personality Composition, student engagement, online discussion.

\section{INTRODUCTION}

Since the beginning of the new century, with the rapid development of information technology, education entered a new era. Online learning breaks the limitation of time and space and is widely used in the fields of elementary education and higher education [1]. For example, MOOCs enables global learners to obtain high-quality learning resources. At the same time, a variety of social networking sites and software make it possible for learners from all over the world to have real-time interaction. As a typical representative of online learning, online discussion is commonly used in higher education because it can effectively promote interaction and feedback among group members, and further support learning achievement [2], [3]. Studies have shown that online discussion can support students' active learning [4], develop higher-order thinking [5], and social awareness and performance [6]. All the above benefits need to be based on students' engagement [7], [8]. In other words, if students' engagement is low, the advantages of online discussion will be hard to show [9]. Previous studies have shown that student engagement is related to academic performance, knowledge acquisition, and motivation [10]. Increasing student engagement is considered as an effective way to solve the problem of "low interest in learning and high dropout rate" [11].

It is generally believed that students' engagement is the product of the interaction between individuals and the

Manuscript received March 6, 2020; revised May 18, 2020.

Xiaojie Zhang and Guang Chen* are with School of Educational Technology, Faculty of Education, Beijing Normal University, Beijing, China (e-mail: zhang_xiaoxiao_jie@163.com, guang@drgchen.com*).

Bing Xu was with Beijing Normal University, Beijing, 100875 China. She is with University of Auckland, Auckland, New Zealand (e-mail: bing.xu@auckland.ac.nz). environment. In online discussion, many facts can affect student engagement, such as students' personality traits, selfefficacy and basic psychological needs. And personality trait is an important aspect [12], [13]. The related researches mostly pay attention to the individual personality traits of students. Group discussion is a process in which students collaborate to solve problems. The personality traits composition of group members will affect student engagement and the effect of collaborative learning. Therefore, this study aims to explore the impact of Big-5 personality composition on student engagement in the online discussion.

\section{LITERATURE REVIEW}

\section{A. Student Engagement in Online Discussion}

Student engagement is defined as the student's psychological commitment and effort to learn, understand, and acquire knowledge, skills, and technology that are directed toward academic work [14]. According to previous studies, student engagement consists of three or four components [15]. The three-component model, which this study used, has been widely accepted [9]. The three components are behavioral engagement, affective engagement, and cognitive engagement.

Behavioral engagement is the concentration of effort, persistence, and energy that students demonstrate in the learning process [16]. It is behavior that reflects the participation of their learning activities, including asking questions, answering questions, actively discussing, and completing tasks [17], [18]. Behavioral engagement in online discussions can be lecture coverage and quiz coverage [19], or log file data(such as discussion posts, annotating and commenting, etc.) [20]. Affective engagement is considered to be the student's emotional response to the group and the learning content, including the degree of student attachment to the teacher and peers (such as group belonging), and the emotional experience of learning content interest, importance, and learning process pleasure [18], [21]. The definition of cognitive engagement given by researchers is slightly different. Some scholars believe that cognitive engagement represents motivation and effort for challenges, and the ability to face failure with optimistic attitude [18], [21]. Some researchers emphasize that the connotation of cognitive engagement should be that students use psychological resources and inputs such as cognitive and metacognitive skill strategies to construct knowledge, solve problems and complete tasks [22].Because of the inseparable relationship between students' motivation and cognitive effort, others think that both of them should be regarded as the connotation of cognitive engagement [4], [23]. 
Studies about CMC (computer mediated communication) focused on both SCMC (synchronous CMC) and ACMC (asynchronous CMC). However, with the development of information technology, the boundaries between synchronous and asynchronous are gradually blurred. Most of the learners are in the "always online" state [24]. Therefore, this study focuses on the online environment to explore student engagement in discuss. Based on existing studies, researchers generally believe that student engagement is the product of the interaction between individuals and the environment [16], [25]. On personal level, personality trait is an important aspect.

\section{B. The Effect of Personality Traits on Student Engagement}

After several generations of psychologists' efforts, the Big Five personality has become the main classification of personality structure. It includes five dimensions. Neuroticism describes an individual's ability to withstand stress. Extroversion reflects the external tendencies of the individual nervous system. Openness reflects the openness and creativity of individuals to experience. Agreeableness reflects the individual's interpersonal orientation in social life. Conscientiousness reflects self-restraint and motivation and a sense of responsibility for achievement.

Studies found that personality was related to the student's engagement and academic achievement [26], [27]. Personality traits may affect students' ability to establish an excellent cooperative relationship with others in group learning and thus affect the collective learning effect and investment. And more nuanced and context-minded perspective on the trait - performance relations is needed [28] Caraway found that in the traditional offline classroom, high school students' emotional engagement will be affected by their personality and self-efficacy [12]. SuLea conducted an empirical study on pre-service students to explore the impact of students' personality traits on job engagement. The results showed that agreeableness and conscientiousness were positively correlated with job engagement, while neuroticism is negatively correlated with job engagement [13]. However, the above conclusions were obtained in the traditional teaching environment and only considered the individual personality traits of students. Group discussion should be investigated because it is a process in which students collaborate to solve problems.

Differences in personality traits among team members could cause differences in behavior, and inconsistencies in such behavior often affect team performance [29]. In other words, the personality traits composition of group members will affect student engagement and the effect of collaborative learning. But few studies had focused on the impact of Big Five personality composition on student engagement. This study aimed to explore the influence of the group personality composition on students' engagement in the online discussion.

\section{The Effect of Personality Traits Combination on Student Engagement}

To explore personality traits combination, there are four indexes: average, variance, maximum, and minimum of the team personality composite. The average of team personality trait is also called Team Personality Elevation (TPE), and the variation of team personality trait is also called Team
Personality Diversity (TPD) [30]. TPE takes the overall level of traits into account, and TPD pays attention to the diversity of members. Maximum and minimum are meaningful when an individual has a significant influence on a group [29], [30].

Neuroticism describes an individual's ability to withstand stress. A student with high scores for neuroticism has higher anxiety levels and is prone to hostile suppression and panic. Studies found that academic performance is negatively correlated with neuroticism [27]. When a team with high TPE of neuroticism, whose members are most likely to be anxious and emotional, its cohesion will decline. And a member who has very high neuroticism may bring negative emotions to the whole group [29]. So, we state the following research hypotheses:

H1a. In online discussion, TPE and the maximum of neuroticism are negatively correlated with student behavioral engagement.

H1b. In online discussion, TPE and the maximum of neuroticism are negatively correlated with student cognitive engagement.

H1c. In online discussion, TPE and the maximum of neuroticism are negatively correlated with student affective engagement.

Extroversion reflects the external tendencies of the individual nervous system. Students with high scores are enthusiastic, positive, adventurous, and social. When a team with senior extroversion members, its cohesion will be stable. On the other hand, when TPD of extroversion is large, the probability of conflict within the group may decrease. So, we state the following research hypotheses:

H2a. In online discussion, the maximum and TPD of extroversion are positively correlated with student behavioral engagement.

H2b. In online discussion, the maximum and TPD of extroversion are positively correlated with student cognitive engagement.

H2c. In online discussion, the maximum and TPD of extroversion are positively correlated with student affective engagement.

Openness reflects the openness and creativity of individuals to experience. A student has low openness score is practical, unwilling to change, willing to obey others' arrangement. If all the students in a group do not have a lower level of openness, it may cause conflicts in group discussions, resulting in lower group engagement. On the other hand, teams with open individuals are more creative, more proactive, will have a good communication effect. And some studies have shown that openness and extroversion are positively correlated with student engagement [26]. So, we state the following research hypotheses:

H3a. In online discussion, TPD and the maximum of openness are positively correlated with student behavioral engagement; TPE and the minimum of openness are negatively correlated with student behavioral engagement.

H3b. In online discussion, TPD and the maximum of openness are positively correlated with student behavioral engagement; TPE and the minimum of openness are negatively correlated with student cognitive engagement.

H3c. In online discussion, TPD and the maximum of 
openness are positively correlated with student behavioral engagement; TPE and the minimum of openness are negatively correlated with student affective engagement.

Agreeableness reflects the individual's interpersonal orientation in social life. Students have a high score of agreeableness, trust others, dislike conflict, and are benevolent. Agreeableness increases mutual attraction among members, teams become more open, and team communication is more fluid. A high agreeableness member may act as a lubricant in the team, while a deficient agreeableness member can destroy team relationships. So, we state the following research hypotheses:

H4a. In online discussion, the maximum, minimum and TPE of agreeableness are positively correlated with student behavioral engagement.

H4b. In online discussion, the maximum, minimum and TPE of agreeableness are positively correlated with student cognitive engagement.

H4c. In online discussion, the maximum, minimum and TPE of agreeableness are positively correlated with student affective engagement.

Conscientiousness reflects self-restraint and motivation and a sense of responsibility for achievement. Studies have shown a positive link between academic achievement and conscientiousness [31]. In a team or group, if the TPD of conscientiousness is large, the member with higher conscientiousness needs to make up for the member with lower conscientiousness, which may reduce the efficiency of the team. So, we state the following research hypotheses:

H5a. In online discussion, the maximum, minimum and TPE of conscientiousness are positively correlated with student behavioral engagement.

H5b. In online discussion, the maximum, minimum and TPE of conscientiousness are positively with student cognitive engagement.

H5c. In online discussion, the maximum, minimum and TPE of conscientiousness are positively correlated with student affective engagement.

\section{RESEARCH DESIGN}

\section{A. Participants}

A total of 97 (15 males, 82 females) undergraduate students participated in this study. They were recruited from two "Human Development" classes in one university in Beijing, China. "Human Development" is a required course for all students majored in Education. There were 46 students (including 9 males) in one class, and 51 students (including 6 males) in the other. The participants were randomly divided into 17 groups (5 or 6 students/group). WeChat discussion groups were set up for each group. The participants were assigned discussion tasks related to the content they had learned in the course.

\section{B. Instruments}

The number of messages sent by students during the discussion was used as the indicator of behavioral engagement (Hsieh \& Tsai, 2012). Skinner, Kindermann, and Furrer's scale (Cronbach's alpha $=0.85$, contains ten questions, such as, I feel good discussing with my partners) was used to measure the affective engagement of students [32]. According to Zhu [33] and Bloom's learning hierarchy, the cognitive engagement was divided into 11 levels in 5 categories (e.g., seeking information, ask deep questions, responding, explanatory). Coding was conducted by two researchers independently, with the Kappa coefficient of 0.753. The Chinese version of the NEO-Personality Inventory [34] was used to measure students' Big-Five personality. The individual Big-Five Personality was measured in the current study.

\section{Data Collection and Analysis}

The online discussion task was posted in the WeChat group, and the discussion task was related to the content of Development Psychology. After the students completed the discussion task within the specified time, each student's affective engagement and Big Five Personality were evaluated via relevant scales. 551 online discussion episodes within the 17 groups were collected to evaluate students behavioral engagement and cognitive engagement. There were missing values in the questionnaires of 7 students. 90 students' data were finally covered.

The Big Five Personality measured in this study was individual. Then the average, variance, maximum, and minimum of Big-5 traits were computed. The Pearson correlation analysis was conducted among the four measures of personality traits and student engagement in the group.

\section{RESUlT AND DisCUSSION}

\section{A. Descriptive Statistics}

Students' personality traits were explored using the Big Five model. It was found that openness was the highest scoring trait characterizing the students $(M=3.61)$. Agreeableness also characterized the students with a high score $(M=3.47)$. However, neuroticism was not found to have a high score $(M=2.85)$; in fact, it was found to score the lowest $($ Min $=1.25)$. The maximum score was found in conscientiousness (Max $=4.83)$. The widest range of scores and differences within a group were found in the neuroticism trait (Variance $=0.359$ ), whereas agreeableness had the smallest range of scores (0.188) (see Table I). Scores were lower than those of Israeli and American college students [35], [36].

TABLE I: THE DESCRIPTIVE STATISTICS OF PERSONALITY TRAIT AND STUDENT ENGAGEMENT

\begin{tabular}{ccccc}
\hline \hline & Min & Max & Mean & Variance \\
\hline Neuroticism & 1.25 & 4.17 & 2.85 & 0.359 \\
Extroversion & 2.25 & 4.35 & 3.45 & 0.213 \\
Openness & 2.58 & 4.5 & 3.61 & 0.216 \\
Agreeableness & 1.83 & 4.33 & 3.47 & 0.188 \\
Conscientiousness & 1.92 & 4.83 & 3.44 & 0.352 \\
$\begin{array}{c}\text { Behavioral } \\
\text { engagement }\end{array}$ & 1 & 23 & 6.12 & 15.052 \\
$\begin{array}{c}\text { Cognitive variance } \\
\text { Affective }\end{array}$ & 4 & 89 & 28.61 & 288.757 \\
engagement & 27 & 46 & 35.56 & 26.609 \\
\hline \hline
\end{tabular}

As for student engagement, the mean of behavioral engagement $(M=6.12)$ meant that on average, each student 
sent 6.12 messages in the discussion. And the lowest engaged student sent 1 message. The mean of cognitive engagement was 28. It meant that most of them did deep discussion. The average of affective engagement was 35.56 (see Table I).

\section{B. Neuroticism Influence}

Regarding neuroticism, we hypothesized that TPE and the maximum of neuroticism were negatively correlated with student behavioral engagement, cognitive engagement and affective engagement. However, as shown in Table II, there was no clear correlation between neuroticism and behavioral engagement or cognitive engagement. As for affective engagement, there was a significant negative correlation between neuroticism maximum and the average of affective engagement $(r=-0.546, P<0.05)$. This is consistent with the hypothesis. A team with a student with high neuroticism score, is most likely to be anxious and emotional. Moreover, the maximum and TPE of neuroticism were negatively correlated with the minimum of student engagement $(r=$ $-0.598, P<0.05 ; r=-0.523, P<0.05)$. It further confirmed our hypothesis that students with high neuroticism are prone to anxiety and uneasiness in online discussions, and thus have lower engagement. The result showed that there was no significant relevance between neuroticism TPE and student engagement. The possible reason might be the small group size and low number of discussions in this study.

TABLE II: THE PEARSON CORRELATION ANALYSIS OF GROUP PERSONALITY NeURoticism TRAit COMBINATION AND STUdENT ENGAGEMENT

\begin{tabular}{|c|c|c|c|c|}
\hline & & Neurot & & \\
\hline & Minimum & Maximum & TPE & TPD \\
\hline $\begin{array}{l}\text { Cognitive } \\
\text { minimum }\end{array}$ & -0.182 & 0.031 & -0.075 & 0.045 \\
\hline $\begin{array}{l}\text { Cognitive } \\
\text { maximum }\end{array}$ & -0.056 & -0.016 & 0.036 & -0.132 \\
\hline $\begin{array}{l}\text { Cognitive } \\
\text { average }\end{array}$ & -0.063 & -0.05 & -0.018 & -0.129 \\
\hline $\begin{array}{l}\text { Cognitive } \\
\text { variance }\end{array}$ & 0.021 & 0.089 & 0.195 & -0.117 \\
\hline $\begin{array}{c}\text { Behavioral } \\
\text { minimum }\end{array}$ & -0.075 & 0.101 & 0.053 & -0.037 \\
\hline $\begin{array}{l}\text { Behavioral } \\
\text { maximum }\end{array}$ & 0.066 & -0.043 & 0.137 & -0.2 \\
\hline $\begin{array}{l}\text { Behavioral } \\
\text { average }\end{array}$ & 0.012 & -0.024 & 0.062 & -0.154 \\
\hline $\begin{array}{c}\text { Behavioral } \\
\text { variance }\end{array}$ & 0.13 & 0.052 & 0.307 & -0.148 \\
\hline $\begin{array}{l}\text { Affective } \\
\text { minimum }\end{array}$ & -0.028 & $-0.598 *$ & $-0.523 *$ & -0.378 \\
\hline $\begin{array}{l}\text { Affective } \\
\text { maximum }\end{array}$ & 0.134 & -0.458 & -0.316 & -0.379 \\
\hline $\begin{array}{l}\text { Affective } \\
\text { average }\end{array}$ & 0.074 & $-0.546^{*}$ & -0.392 & -0.401 \\
\hline $\begin{array}{l}\text { Affective } \\
\text { variance }\end{array}$ & 0.159 & -0.202 & -0.091 & -0.211 \\
\hline
\end{tabular}

\section{Extroversion Influence}

We hypothesized that the maximum and TPD of extroversion are positively correlated with student behavioral engagement, cognitive engagement and affective engagement. However, as shown in Table III, there was no clear correlation between extroversion and behavioral engagement or cognitive engagement. As for affective engagement, there was no significant correlation between extroversion maximum and affective engagement. And there were significant positive correlations between extroversion tpe and affective engagement's maximum, average and variance $(r=0.746, P<0.001 ; r=0.686, P<0.001 ; r=0.716$, $P<0.001)$. Moreover, there were significant positive correlations between extroversion minimum and affective engagement's maximum, average and variance $(r=0.613, P$ $<0.001 ; r=0.548, P<0.001 ; r=0.502, P<0.001)$. This meant that for extroversion, the student with lowest score determine the overall engagement of the group. That is to say, in online discussions, the difference in extroversion of members did not promote the discussion. On the contrary, when all the students in the group were extroverted, the students' emotional involvement was high. It might be because that, in the online discussion, students' non-verbal information is keep apart by the screen. In order to achieve high engagement, students need to be more willing to express themselves in online discussions than in face-to-face discussions.

TABLE III: THE PEARSON CORRELATION ANALYSIS OF GROUP PERSONALITY EXTROVERSION TRAIT COMBINATION AND STUDENT ENGAGEMENT

\begin{tabular}{|c|c|c|c|c|}
\hline & \multicolumn{4}{|c|}{ Extroversion } \\
\hline & Minimum & Maximum & TPE & TPD \\
\hline $\begin{array}{l}\text { Cognitive } \\
\text { minimum }\end{array}$ & 0 & -0.035 & -0.093 & -0.107 \\
\hline $\begin{array}{l}\text { Cognitive } \\
\text { maximum }\end{array}$ & -0.12 & 0.043 & -0.009 & 0.166 \\
\hline $\begin{array}{c}\text { Cognitive } \\
\text { average }\end{array}$ & -0.001 & -0.003 & 0.002 & 0 \\
\hline $\begin{array}{l}\text { Cognitive } \\
\text { variance }\end{array}$ & -0.231 & -0.087 & -0.092 & 0.24 \\
\hline $\begin{array}{l}\text { Behavioral } \\
\text { minimum }\end{array}$ & -0.006 & 0.001 & -0.044 & -0.047 \\
\hline $\begin{array}{l}\text { Behavioral } \\
\text { maximum }\end{array}$ & -0.143 & -0.074 & -0.09 & 0.188 \\
\hline $\begin{array}{c}\text { Behavioral } \\
\text { average }\end{array}$ & 0.006 & -0.037 & 0.012 & 0.026 \\
\hline $\begin{array}{c}\text { Behavioral } \\
\text { variance }\end{array}$ & -0.317 & -0.207 & -0.248 & 0.326 \\
\hline $\begin{array}{l}\text { Affective } \\
\text { minimum }\end{array}$ & 0.381 & 0.294 & 0.417 & -0.16 \\
\hline $\begin{array}{l}\text { Affective } \\
\text { maximum }\end{array}$ & $0.613 * *$ & 0.41 & $\begin{array}{c}0.746 \\
* * *\end{array}$ & -0.301 \\
\hline $\begin{array}{l}\text { Affective } \\
\text { average }\end{array}$ & $0.548 *$ & 0.376 & $0.686^{* *}$ & -0.218 \\
\hline $\begin{array}{l}\text { Affective } \\
\text { variance }\end{array}$ & $0.502 *$ & 0.338 & $0.716^{* * *}$ & -0.202 \\
\hline
\end{tabular}

\section{Openness Influence}

Regarding openness, we hypothesized that TPD and the maximum of openness were positively correlated with student engagement; TPE and the minimum of openness were negatively correlated with student behavioral engagement.

TABLE IV: THE PEARSON CORRELATION ANALYSIS OF GROUP PERSONALITY OPENNESS TRAIT COMBINATION AND STUDENT ENGAGEMENT

\begin{tabular}{ccccc}
\multicolumn{5}{c}{ ENGAGEMENT } \\
\hline \hline & Minimum & $\begin{array}{c}\text { Openness } \\
\text { Maximum }\end{array}$ & TPE & TPD \\
\hline $\begin{array}{c}\text { Cognitive } \\
\text { minimum }\end{array}$ & 0.245 & -0.14 & 0.046 & -0.175 \\
$\begin{array}{c}\text { Cognitive } \\
\text { maximum }\end{array}$ & 0.233 & 0.159 & 0.454 & -0.131 \\
$\begin{array}{c}\text { Cognitive } \\
\text { average }\end{array}$ & 0.347 & -0.05 & 0.29 & -0.275 \\
$\begin{array}{c}\text { Cognitive } \\
\text { variance } \\
\text { Behavioral } \\
\text { minimum }\end{array}$ & 0.074 & 0.255 & 0.473 & -0.015 \\
\hline
\end{tabular}




\begin{tabular}{ccccc}
\hline $\begin{array}{c}\text { Behavioral } \\
\text { maximum }\end{array}$ & $0.54 *$ & 0.109 & $0.518^{*}$ & -0.311 \\
$\begin{array}{c}\text { Behavioral } \\
\text { average }\end{array}$ & 0.45 & -0.063 & 0.347 & -0.306 \\
$\begin{array}{c}\text { Behavioral } \\
\text { variance }\end{array}$ & 0.469 & 0.283 & $0.532^{*}$ & -0.165 \\
$\begin{array}{c}\text { Affective } \\
\text { minimum }\end{array}$ & 0.434 & -0.014 & 0.323 & -0.319 \\
$\begin{array}{c}\text { Affective } \\
\text { maximum } \\
\text { Affective } \\
\text { average }\end{array}$ & 0.139 & 0.01 & 0.364 & -0.105 \\
$\begin{array}{c}\text { Affective } \\
\text { variance }\end{array}$ & -0.101 & 0.065 & 0.481 & -0.134 \\
\hline \hline$* p<0.05, * * p<0.01, * * * p<0.001$ & 0.072 & 0.314 & 0.162 \\
\hline
\end{tabular}

However, as shown in Table IV, there was no clear correlation between student engagement and TPD and the maximum of openness. There were significant positive correlations between the minimum and TPE of openness and the maximum of affective engagement $(r=0.54, P<0.05 ; r=$ $0.518, P<0.05)$. This was contrary to the hypothesis. It illustrated that the high openness of group members (rich feelings and strong curiosity), including the high openness of students with lowest scores, would stimulate the discussion enthusiasm of other members of the group.

\section{E. Agreeableness Influence}

Regarding agreeableness, we hypothesized that the maximum, minimum and TPE of agreeableness were positively correlated with student behavioral, cognitive and affective engagement. However, as shown in Table V, there was no clear correlation between student engagement and the minimum of agreeableness, and there was no obvious correlation between behavioral and cognitive engagement and the maximum and TPE of agreeableness.

TABLE V: THE PEARSON CORRELATION ANALYSIS OF GROUP PERSONALITY AGREEABLENESS TRAIT COMBINATION AND STUDENT ENGAGEMENT

\begin{tabular}{|c|c|c|c|c|}
\hline & \multicolumn{4}{|c|}{ Agreeableness } \\
\hline & Minimum & Maximum & TPE & TPD \\
\hline $\begin{array}{l}\text { Cognitive } \\
\text { minimum }\end{array}$ & 0.282 & 0.346 & 0.262 & -0.264 \\
\hline $\begin{array}{l}\text { Cognitive } \\
\text { maximum }\end{array}$ & -0.015 & 0.276 & 0.185 & 0.107 \\
\hline $\begin{array}{l}\text { Cognitive } \\
\text { average }\end{array}$ & 0.231 & 0.382 & 0.316 & -0.143 \\
\hline $\begin{array}{l}\text { Cognitive } \\
\text { variance }\end{array}$ & -0.255 & 0.113 & -0.031 & 0.32 \\
\hline $\begin{array}{l}\text { Behavioral } \\
\text { minimum }\end{array}$ & 0.313 & 0.345 & 0.254 & -0.314 \\
\hline $\begin{array}{l}\text { Behavioral } \\
\text { maximum }\end{array}$ & -0.119 & 0.341 & 0.173 & 0.258 \\
\hline $\begin{array}{c}\text { Behavioral } \\
\text { average }\end{array}$ & 0.152 & 0.459 & 0.32 & -0.038 \\
\hline $\begin{array}{l}\text { Behavioral } \\
\text { variance }\end{array}$ & -0.401 & 0.104 & -0.098 & $0.498^{*}$ \\
\hline $\begin{array}{l}\text { Affective } \\
\text { minimum }\end{array}$ & 0.287 & 0.462 & $0.615^{* *}$ & -0.017 \\
\hline $\begin{array}{l}\text { Affective } \\
\text { maximum }\end{array}$ & 0.343 & 0.453 & $0.561 *$ & -0.175 \\
\hline $\begin{array}{l}\text { Affective } \\
\text { average }\end{array}$ & 0.335 & $0.547^{*}$ & $0.635 * *$ & -0.095 \\
\hline $\begin{array}{l}\text { Affective } \\
\text { variance }\end{array}$ & 0.259 & 0.394 & 0.353 & -0.181 \\
\hline
\end{tabular}

There were significant positive correlations between the TPE of agreeableness and the minimum, maximum and average of affective engagement $(r=0.615, P<0.01 ; r=$ $0.561, P<0.05 ; r=0.635, P<0.01)$. This was consistent with the hypothesis. In the online discussion, students with high agreeableness had high affective engagement and can prove the group engagement.

\section{F. Conscientiousness Influence}

We hypothesized that the maximum, minimum and TPE of conscientiousness were positively correlated with student behavioral engagement, cognitive engagement and affective engagement. However, as shown in Table VI, there was no clear correlation between student behavioral and cognitive engagement and the minimum and TPE of conscientiousness, and there was no obvious correlation between affective engagement and the maximum of conscientiousness.

TABLE VI: THE PEARSON CORRELATION ANALYSIS OF GROUP PERSONALITY CONSCIENTIOUSNESS TRAIT COMBINATION AND STUDENT ENGAGEMENT

\begin{tabular}{|c|c|c|c|c|}
\hline & \multicolumn{4}{|c|}{ Conscientiousness } \\
\hline & Minimum & Maximum & TPE & TPD \\
\hline $\begin{array}{l}\text { Cognitive } \\
\text { minimum }\end{array}$ & -0.16 & 0.115 & 0.057 & 0.287 \\
\hline $\begin{array}{l}\text { Cognitive } \\
\text { maximum }\end{array}$ & -0.416 & -0.298 & -0.223 & 0.267 \\
\hline $\begin{array}{l}\text { Cognitive } \\
\text { average }\end{array}$ & -0.323 & -0.14 & -0.112 & 0.295 \\
\hline $\begin{array}{l}\text { Cognitive } \\
\text { variance }\end{array}$ & -0.373 & $-0.49 *$ & -0.261 & 0.071 \\
\hline $\begin{array}{c}\text { Behavioral } \\
\text { minimum }\end{array}$ & -0.305 & -0.001 & -0.123 & 0.342 \\
\hline $\begin{array}{l}\text { Behavioral } \\
\text { maximum }\end{array}$ & -0.437 & -0.455 & -0.391 & 0.255 \\
\hline $\begin{array}{c}\text { Behavioral } \\
\text { average }\end{array}$ & -0.409 & -0.201 & -0.251 & 0.38 \\
\hline $\begin{array}{c}\text { Behavioral } \\
\text { variance }\end{array}$ & -0.268 & $-0.573^{*}$ & -0.341 & 0.006 \\
\hline $\begin{array}{l}\text { Affective } \\
\text { minimum }\end{array}$ & $-0.624 * *$ & -0.3 & $-0.546^{*}$ & 0.467 \\
\hline $\begin{array}{l}\text { Affective } \\
\text { maximum }\end{array}$ & $-0.726 * * *$ & -0.062 & $-0.683 * *$ & $0.713 * * *$ \\
\hline $\begin{array}{l}\text { Affective } \\
\text { average }\end{array}$ & $-0.747 * * *$ & -0.156 & $-0.653 * *$ & $0.686^{* *}$ \\
\hline $\begin{array}{l}\text { Affective } \\
\text { variance }\end{array}$ & $-0.549 *$ & 0.143 & $-0.487 *$ & $0.681 * *$ \\
\hline
\end{tabular}

Quite unexpectedly, we found the minimum of conscientiousness was negatively correlated with affective engagement's minimum, maximum, average and variance $(r$ $=-0.624, p<0.01 ; r=-0.726, p<0.001 ; r=-0.747, p<0.001$; $r=-0.549, p<0.05)$, and the TPE was negatively correlated with student affective engagement's minimum, maximum, average and variance $(r=-0.546, p<0.05 ; r=-0.683, p<$ $0.01 ; r=-0.653, p<0.01 ; r=-0.487, p<0.05)$.

In addition, the TPD of conscientiousness was positively correlated with affective engagement average $(r=0.686, p<$ 0.01). The greater the difference in students' conscientiousness, the higher the group engagement. That was contrary to previous research [29]. This might be due to the unique nature of the online discussion environment or other reasons.

\section{CONCLUSION}

The current study explored the influence of personality trait combinations on student engagement in the online discussion. From the above analysis and discussion, it could be seen that the combination of the Big-Five personalities in the group could have an impact on student engagement, 
especially affective engagement. When organizing students' online discussion, the instructors need to carefully consider the personality characteristics of the group members and try to make the variance of conscientiousness and agreeableness of the group members larger. When there is a lack of extroverted and open members in the group, the instructors should properly guide students to discuss tasks. Also, when there are highly neurotic students in the group, teachers should pay special attention to the group to avoid excessive conflicts within the group.

Almost exclusively, affective engagement variables become significant, which may indicate that the survey procedures were not well carried out. Further studies should be conducted to explore the factors influencing cognitive and behavioral engagement and consider how group personality traits might change over time. There are also some other limitations in this study: the sample size was small, and the moderating effect of task types on student engagement was not taken into account. For different task types, the influence of personality trait combinations on students' engagement might be different. Future research can recruit more participants based on this study and add the moderating effect of task type. Moreover, future research should distinguish different trait compositions between well-functioning groups and non-effective groups.

\section{CONFLICT OF INTEREST}

The authors declare no conflict of interest.

\section{AUTHOR CONTRIBUTIONS}

Guang Chen and Bing Xu conducted the research; Guang Chen and Xiaojie Zhang analyzed the data; Xiaojie Zhang, Guang Chen and Bing Xu wrote the paper; all authors had approved the final version.

\section{REFERENCES}

[1] I. E. Allen and J. Seaman, Going the Distance: Online Education in the United States, Sloan Consortium, 2011.

[2] I. Srba, M. Savic, M. Bielikova, M. Ivanovic, and C. Pautasso, "Employing community question answering for online discussions in university courses: Students' perspective," Comput. Educ., vol. 135, pp 75-90, Jul. 2019.

[3] C. H. Wang, "Questioning skills facilitate online synchronous discussions," J. Comput. Assist. Learn., vol. 21, no. 4, pp. 303-313, Aug. 2005

[4] L. A. Schindler, G. J. Burkholder, O. A. Morad, and C. Marsh, "Computer-based technology and student engagement: A critical review of the literature," Int. J. Educ. Technol. High. Educ., vol. 14, p. 25, Oct. 2017.

[5] G. Collison, Facilitating Online Learning: Effective Strategies for Moderators, Madison, Wis.: Atwood Pub, 2000.

[6] A. P. Rovai, "Strategies for grading online discussions: Effects on discussions and classroom community in internet-based university courses," J. Comput. High. Educ., vol. 15, no. 1, pp. 89-107, Sep. 2003.

[7] C. Beer, K. Clark, and D. Jones, Indicators of Engagement, 2010.

[8] N. A. Shukor, Z. Tasir, H. V. Meijden, and J. Harun, "A predictive model to evaluate students' cognitive engagement in online learning," Procedia - Social and Behavioral Sciences, vol. 116, pp. 4844-4853, Feb. 2014.

[9] L. Ding, C. Kim, and M. Orey, "Studies of student engagement in gamified online discussions," Comput. Educ., vol. 115, pp. 126-142, Dec. 2017

[10] W. Chen, C.-K. Looi, and S. Tan, "What do students do in a F2F CSCL classroom? The optimization of multiple communications modes," Computers \& Education, vol. 55, no. 3, pp. 1159-1170, Nov. 2010.
[11] National Research Council and Institute of Medicine, Engaging Schools: Fostering High School Students' Motivation to Learn, Washington, DC: National Academies Press, 2004.

[12] K. Caraway, C. M. Tucker, W. M. Reinke, and C. Hall, "Self-efficacy, goal orientation, and fear of failure as predictors of school engagement in high school students," Psychol. Schools, vol. 40, no. 4, pp. 417-427, Jul. 2003.

[13] C. Sulea, I. Van Beek, P. Sarbescu, D. Virga, and W. B. Schaufeli, "Engagement, boredom, and burnout among students: Basic need satisfaction matters more than personality traits," Learn. Individ. Differ., vol. 42, pp. 132-138, Aug. 2015.

[14] F. M. Newmann, "Reducing student alienation in high schools Implications of theory," Harvard Educational Review, vol. 51, no. 4 pp. 546-564, 1981.

[15] E. R. Kahu, "Framing student engagement in higher education," Studies in Higher Education, vol. 38, no. 5, pp. 758-773, Jun. 2013.

[16] J. A. Fredricks, P. C. Blumenfeld, and A. H. Paris, "School Engagement: Potential of the concept, state of the evidence," Review of Educational Research, vol. 74, no. 1, pp. 59-109, 2004.

[17] S. H. Birch and G. W. Ladd, "The teacher-child relationship and children's early school adjustment," Journal of School Psychology, vol. 34, pp. 934-946, Jan. 1997.

[18] E. Skinner and M. J. Belmont, "Motivation in the classroom Reciprocal effects of teacher behavior and student engagement across the school year," Journal of Educational Psychology, vol. 85, pp 571-581, Dec. 1993.

[19] Q. Li and R. Baker, "The different relationships between engagement and outcomes across participant subgroups in massive open online courses," Comput. Educ., vol. 127, pp. 41-65, Dec. 2018.

[20] S. Goggins and W. Xing, "Building models explaining student participation behavior in asynchronous online discussion," Computers \& Education, vol. 94, pp. 241-251, Mar. 2016.

[21] J. P. Connell and J. G. Wellborn, "Competence, autonomy, and relatedness: A motivational analysis of self-system processes," Journal of Personality \& Social Psychology, vol. 65, pp. 43-77, 1991.

[22] P. R. Pintrich and E. V. Groot, "Motivated and self-regulated learning components of classroom academic performance," Journal of Educational Psychology, vol. 82, pp. 33-40, Mar. 1990.

[23] National Center for School Engagement, "Quantifying school engagement research report," 303 E. 17th Avenue, Suite 400 Denver, 80203, Dec. 2006.

[24] Y. Wang, W.-C. Han, and N.-S. Chen, "Exploring the affordances of WeChat for facilitating teaching, social and cognitive presence in semi-synchronous language exchange," Australasian Journal of Educational Technology, vol. 32, no. 4, 2016.

[25] M. A. Lawson and H. A. Lawson, "New conceptual frameworks for student engagement research, policy, and practice," Rev. Educ. Res., vol. 83, no. 3, pp. 432-479, Sep. 2013.

[26] M. Komarraju and S. J. Karau, "The relationship between the big five personality traits and academic motivation," Personality and Individual Differences, vol. 39, no. 3, pp. 557-567, Aug. 2005.

[27] K. Laidra, H. Pullmann, and J. Allik, "Personality and intelligence as predictors of academic achievement: A cross-sectional study from elementary to secondary school," Personality and Individual Differences, vol. 42, no. 3, pp. 441-451, Feb. 2007.

[28] N. D. Brandt, C. M. Lechner, J. Tetzner, and B. Rammstedt, "Personality, cognitive ability, and academic performance: Differential associations across school subjects and school tracks," Journal of Personality, 2019.

[29] M. R. Barrick, G. L. Stewart, M. J. Neubert, and M. K. Mount, "Relating member ability and personality to work-team processes and team effectiveness," J. Appl. Psychol., vol. 83, no. 3, pp. 377-391, Jun. 1998.

[30] G. A. Neuman, S. H. Wagner, and N. D. Christiansen, "The relationship between work-team personality composition and the job performance of teams," Group \& Organization Management, vol. 24, no. 1, pp. 28-45, Mar. 1999.

[31] M. Komarraju, S. J. Karau, and R. R. Schmeck, "Role of the big five personality traits in predicting college students' academic motivation and achievement," Learning and Individual Differences, vol. 19, no. 1, pp. 47-52, Jan. 2009.

[32] E. A. Skinner, T. A. Kindermann, J. P. Connell, and J. G. Wellborn, "Engagement as an organizational construct in the dynamics of motivational development," Handbook of Motivation in School, pp. 223-245, 2009.

[33] E. Zhu, "Interaction and cognitive engagement: An analysis of four asynchronous online discussions," Instr Sci, vol. 34, no. 6, p. 451, Nov. 2006.

[34] X. Dai, S. Yao, T. Cai, \& J. Yang, Research on the Application of the NEO Personality Questionnaire Revision in China. 
[35] S. Balci, J. Cakiroglu, and C. Tekkaya, "Engagement, exploration, explanation, extension, and evaluation (5E) learning cycle and conceptual change text as learning tools," Biochemistry and Molecular Biology Education, vol. 34, no. 3, pp. 199-203, May 2006.

[36] S. M. Suldo, D. R. Minch, and B. V. Hearon, "Adolescent life satisfaction and personality characteristics: Investigating relationships using a five factor model," J. Happiness Stud., vol. 16, no. 4, pp. 965-983, Aug. 2015

Copyright $\odot 2020$ by the authors. This is an open access article distributed under the Creative Commons Attribution License which permits unrestricted use, distribution, and reproduction in any medium, provided the original work is properly cited (CC BY 4.0).

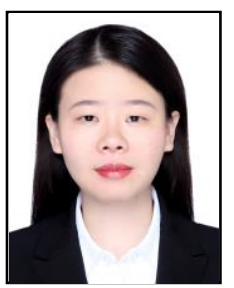

Xiaojie Zhang was born on Feb. 1st, 1993 in Shandong province of China, and holds the bachelor and master degrees in educational technology of Ocean University of China, Qingdao, China. Xiaojie' $s$ research interests are about online education and student engagement.

She is currently studying as a master student in the Educational Technology Department of Beijing Normal University in Beijing, China. She published a SSCI journal literature on online one-on-one education (Interactive Learning Environments, 2019)

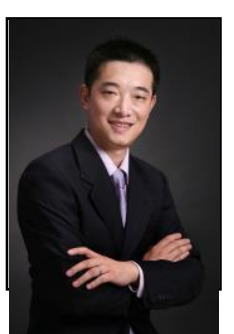

Guang Chen was born in Beijing, China and received his $\mathrm{PhD}$, master, and bachelor degree in developmental and educational psychology from School of Psychology, Beijing Normal University. Guang's major field of study was cognitive development and smart learning environments.

$\mathrm{He}$ is an assistant professor in the School of Educational Technology, Faculty of Education, Beijing Normal University. He published an e-textbook: Definition, Functions and Key Technical
Issues (Open Education Research, 2012). He published a comparison of reading comprehension across paper, computer screens, and tablets (Journal of Computers in Education, 2014). He also published an e-textbook in K-12 Education: A Case Study in Beijing (The New Development of Technology Enhanced Learning, 2014). His major field of study is smart learning environments.

Dr. Chen is the leader of a National Social Science Fund Project, a Beijing Municipal Commission of Education Fund Project, and more than 10 other research projects. He is reviewer of several SSCI journals and PC member of more than 10 international conferences and workshops

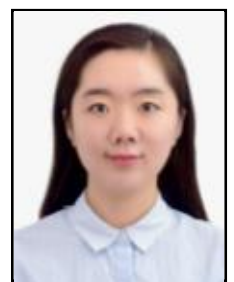

Bing Xu was born on Feb. 16th, 1993, and holds the bachelor and master degrees in educational technology, Beijing Normal University, Beijing, China. Bing's research interests are about student engagement and CSCL.

She worked as a research intern in Athabasca University (Canada), and as an instruction designers (intern) in Tomorrow Advancing Life (China). She published exploring blockchain technology and its potential applications for education (Smart Learning Environments, 2018). Now, as a PhD student, Bing Xu is studying in The University of Auckland, Auckland, New Zealand, focusing on learning analytics, online learning and student engagement. 